\title{
Academic and Industrial Research on Islamic Finance: Why it Matters
}

\author{
Noor Inayah Yaakub \\ School of Management \\ Faculty of Economics \& Management \\ Universiti Kebangsaan Malaysia \\ inayahyaakub@gmail.com
}

\author{
Wan Kamal Mujani \\ Dept of Arabic Studes and Islamic Civilisation \\ Faculty of Islamic Studies \\ Universiti Kebangsaan Malaysia \\ inamal@yahoo.com
}

\begin{abstract}
This paper explores the significance of the findings of academic research on Islamic finance and its suitability to serve the needs of the industry. The study recommends strategic directions for developing a plausible link and connection between industries and academic research.
\end{abstract}

Keywords-component; Islamic Finance, maqasid, industry, academic research

\section{INTRODUCTION}

The Islamic banking industry has seen an enormous growth in the past twenty years in the space of Malaysia. Malaysia has a strong a nd comprehensive Islamic financial system with a robust business driven regulatory regime and legal framework. The country today is the world's third largest market for Islamic banking, takaful and sukuk. Its Islamic capital market tripled in size to a value of RM1.05 over the past decade [1-2]. The above background nevertheless, must be linked with the role of aca demic research in order to see whether academic research is supportive to the country's strong Islamic financial system. Not surprisingly, there has been considerable debate on incongruity of Islamic Finance and Academic Research.

\section{ACADEMIC AND INDUSTRIAL RESEARCH}

It is questionable whether the vital element of divinity [3] of Islamic finance needs a different set of research findings that suits the industrial needs? Similarly, from academic point of view where the goal of conducting a particular research is driven on the belief that it provides frontiers of knowledge through generation of research results and free dissemination as well as to tr ain highly qualified researchers for industry, government and academia, wou ld academic research on Islamic finance should derive from a difference perspective?[45]

\section{A. Academic and Industry Research Freedom}

A more interesting views may be looked at the statement by some well-known scholars where they said "In business, everything begins with the profit motive. Just the very idea of research is geared towar ds a product rather than knowledge itself [6]. The most critical factor in determining whether a scientist, for example is go ing to be s uccessful in making the transition from the university to the private sector is the ability to buy into that point of view." To the $\mathrm{m}$, that product-driven mission means that research freedom can be limited. In most companies, research topics are largely chosen by the business or marketing departments where research projects are regularly evaluated against their objectives, targeted costs, and timeline [7]. "In industry, there is always the tendency in the management to have more control, get more accountability, measure things and deadlines.

\section{SHARIA COMPLIANT AND SHARIA BASED-PRODUCT}

There is also great deal of confusion, misinterpretation and misunderstanding about Islamic finance in general, especially as applied to the modern Islamic banking practices [8]. Plethora of debates is taking place within the Islamic finance industry on the nature and characteristics of financial instruments which seek to comply with the principles of Shariah.

\section{A. Misreprentation}

More interestingly, anecdotal evidence shows that many of the conventional products can be redrafted as Sharia-compliant products, so that the differences are smaller than ex pected. Shari'ah compliant products are said to be those $\mathrm{p}$ roducts which mimic their conventional counterparts by making necessary cosmetic changes to satisfy Shari'ah sensitivities.

\section{B. Not a Different Financial System}

Other economists have argued that Islamic finance, is a different way of structuring financial dealings; but, it is not a totally different financial system [9]. Shari'ah-based products, on the other hand, are said to be those which seek to observe the real spirit of Shari'ah and are observant of Shari'ah principles in substance. The debates has somehow resulted in mainstream Islamic finance products being classified by some as either Shari' ah compliant or Shari'ah-based [10-11]. Recent Musharaka transactions based on Shirkat al Aqd and Musharaka Mutanakisa principles have been structured so that:

- The financier contributes cash and the customer makes a contribution-in-kind to create a pool of assets, which are managed by an independent service contractor;

- The customer grants a purchase undertaking to the financier under which it undertakes to purchase the financier' $s$ share in the pool of assets on a de ferred payment basis and at cost price; 
- Each time the customer makes a deferred payment to the financier, the financier' $s$ interest in the pool of assets diminishes and the customer' $\mathrm{s}$ share in the asset increases;

- Simultaneously with the above, the financier leases its beneficial share in the pool of assets to the customer; and

- Title to the pool of assets is transferred to the customer once the financier receives full payment of its interest in the pool of assets.

\section{Shirkatu-al-aqd}

There can be no denying that Islamic financing products that are structured upon Shirkat al Aqd principles fall with the category of Shari'ah based. This is due to the fact that, in line with the fundamental principles of Islamic finance, the financier is exposed to a wider variety of risks than just the credit risk of the customer. In a transaction based on Shirkat al Aqd principles, the financier has no certainty of receiving a profit on its c apital and has no certainty of having its capital repaid. Musharaka is championed to be the most Shari'ahbased Islamic financing technique because it has traditionally been viewed purely as an equity instrument. The use of purchase undertakings and leas ing techniques in Musharaka products based on Shirkat al Aqd and Musharaka Mutanakisa principles, however, are said to give such Musharaka products debt like characteristics, thereby merely making them Shari'ah compliant.

\section{Further Classification of Shirkat Al-aqd}

- Shirkat-ul-Amwal where all the partn ers invest some capital into a commercial enterprise.

- Shirkat-ul-A'mal where all the partners jointly undertake to render some services for their customers, and the fee charged from them is distributed among them according to an agreed ratio. For example, if two persons agree to undertake tailoring services for their customers on the condition that the wages so earned will go t o a joint pool which shall be distr ibuted between them irrespective of the size of work each partner has actually done, this partners hip will be a shirkat-ul-a'mal which is also called Shirkat-uttaqabbul or Shirkat-us-sana'i' or Shirkat-ul-abdan.

- The third kind of Shirkat-ul-'aqd is Shirkat-ul-wujooh. Here the partners have no investment at all. All they do is that they purchase the commodities on a deferred price and se 11 them at spot. The p rofit so earned is distributed between them at an agreed ratio.In your paper title, if the w ords "that uses" can accurately replace the word "using", capitalize the "u"; if not, keep using lower-cased.

- The word 'Musharaka' is derived from the Arabic word shirka, which means 'sharing'. In the context of Shari'ah compliant financing, Shrikat al Aqd means the creation of a joint venture partnership in which all the partners share the profit or loss generated by that joint venture [12-13]. Shirkat al Milk can be translated to mean the joint ownership by two or more persons of a particular asset or assets.

- The Mejella (1329) define it as an "Agreement for association on the condition that the capital and its benefit be common between two or more persons". Meanwhile, Ibn Arfa defined it as: "An agreement between two or more persons to carry out a particular business with the $\mathrm{v}$ iew of sharing profits by joint investment". Another Muslim jurist, Mohammad Akram Khan defines a musharakah or partnership as: "A contract between two persons who launch a business of financial enterprise to make profit" [14].

- One of the fundamentals of rule of equity for academic research which is related to legal i ssues of Islamic finance is that the rule of Equity will not permit justice to be withheld just because of a technicality. Professors are keener to follow the rule that fo rmalities that frustrate justice will be disregarded and a better approach found for each case. Equity enforces the spirit rather than the letter of the law alone. Courts of equity do not disregard the words used $\mathrm{i} n$ a written document, but they do seek to give effect to what was the intention of the parties. Parkin v Thorold (1852) 16 Beav 59, 66. Hence, in the wo rds of Romilly MR: If they ... find that by insisting on the form, the substance will be defeated, they hold it to be inequitable to allow a person to insist on such form and thereby defeat the substance. Parkin v Thorold (1852) 16 Beav 59 at 6667.

- However, In facing or sol ving current issues in the aspects of social, economics, politics and finance, the application of Maqasid al-Shari'ah is an important element that needs to be incorporated by all Muslims. [15-17].In addition, there should be continuous emphasize on the importance of Maqasid al- Shari'ah in all Islamic finance fields. Isla mic finance distinguishes itself from conventional counterpart in its professed compliance with principles of Islamic law, or Shari'ah. Fundamentally, Maqasid al-Shari'ah reveals the dignified view of Islam which has to be observed entirely, not partially, as Islam is an absolute and integrated pattern of life and its purpose includes the complete life, personal and public; in this worl $\mathrm{d}$ and the Hereafter.

\section{CONCLUSION}

It is i mportant to observe Shari'ah rulings in Islamic financial transactions. It should not be a practice by only highlighting on the lawful forms of a contract to prevail and the only requirement to validate the contract [15]. Ins tead, the matter that has greater implications to the implementation of Maqasid al-Shari'ah must be observed, in particular when structuring a financial product. 


\section{A. Forms vs Substance}

Islamic finance must make sure that all of its transactions are Shari'ah-compliant not only in its forms and lawful procedures but more significantly in $\mathrm{i}$ ts substance and economic matters which are premised on the ob jectives outlined by Shari'ah. Academic research on Islamic finance must be considered as main contributions to the industry in order to i nnovate a novel ty products for Islamic finance industries.

1) It is the banking business today to develop products and services that are Shari'ah-compliant or genuine from Islamic viewpoint without reducing the importance of the business features of being competitive, profitable and viable in the long run..

a) It is material to consider several relevant issues especially what should be the foundation in justifying whether a product is Shari'ah-compliant or not?

b) How to derive genuine methods in fiqh when resolving whether a contract is legitimate and within the context of Shari'ah perspectives?

c) Whether the issue of of form rather than substance comes material at this point?

\section{B. Musharaka Contracts}

There is a lmost unanimous consensus amongst Shari'ah scholars and other players in the Islamic finance industry that Musharaka is the purest form of Islamic financing. Islamic finance products structured according to Musharaka principles should therefore, in theory at least, fall into the Shari'ah-based category described above.

The element of use of the purchase undertaking is said to violate traditional Musharaka principles, which are based on the concepts of risk and reward, as the financier is effectively guaranteed a return of its capital investment. What more is the leasing arrangements are said to provide the financier with a pre-determined 'profit' return on its capital investment through the receipt of rental payments and this, it is said, co ntradicts traditional Musharaka concepts relating to profit sharing.

\section{Figures and Tables}

1) Narrated by 'Umar al-Khattab, recorded by Al-Bukhari, Sahih Al-Bukhari a hadith that is used by the scholars to justify their positions, namely "matters are determined by intention." Based on this hadith, legality of all contracts must be established by intention (niyyah). It is the rationale or matter of the contract, not mere looking at its structure or formation alone. Scholars like Imam Shafie however, stated that it is unreasonable to decide on the legality of contracts by implication of intention, as it is complex and sometimes improbable to categorize the intention of the contracting parties.

A closer look at the disclaimer clause standard below developed by the banking industries is an example of the practice of forms rather than substance; (Emphasis is added)[18].
"We have reviewed the documents as per Appendix A forwarded by the Manager for the 2nd Quarter for 2005 ("the Reporting Period"). [19] We have examined the same and to the extent as such being presented to us, we are of the opinion that the Manager has managed the Fund in accordance with the Shariah.[19]-[21]. In facing or solving current issues in the aspects of social, economics, politics and $\mathrm{f}$ inance, the application of Maqasid al-Shari'ah is an important element that needs to be incorporated by all Muslims.[22][23].

\section{ACKNOWLEDGMENT}

The paper is part of the research sponsored by Long Research Grant Scheme (LRGS/BU/2011/UKM/CMN) Ministry of Education, Malaysia.

\section{REFERENCES}

[1] Ahamed Kameel Mydin Meera and Dzuljastri Abdul Razak. 2009. Home Financing through the Musharakah MutanaqisahContracts: Some Practical Issues J.KAU: Islamic Econ., Vol. 22 No. 1, pp: 121-143.

[2] Akram Khan M. (1990) Glossary of Islamic Economic, MANSELL, London, p. 100

[3] al-Zuhayli, Wahaba (2003) Islamic Jurisprudence and Its Proofs, Dar alFikr, p. 33; 56.

[4] Arun S. Mujumdar. 2004. Presentation to National University of $\begin{array}{lll}\text { Singapore } & \text { research }\end{array}$ http://serve.me.nus.edu.sg/arun/file/resources/Academic_Vs_Industrial_ R\&D.pdf

[5] Katherine J. Strandburg. 2009. User Innovator Community Norms at the Boundary between Academic and Industry Research Fordham Law Review, Vol. 77

[6] Beck, Thorsten, Demirgüç-Kunt, Asli and Merrouche, Ouarda, Islamic vs. Conventional Banking: Business Model, Efficiency and Stabilit y (October 1, 2010). World Bank Policy Research Working Paper Series, Vol. , pp. -, 2010.

[7] Bendjilali, Boualem and Khan, Tariqullah (1995) Eco nomics of Diminishing Musharakah. Research Paper No. 31.Jeddah: Islamic Research and Training Institute (IRTI), IDB.

[8] Dusuki, A. W., \& Abozaid, A. (2007). The Challenges of Realising Maqasid al-Shari ah in Islamic Banking and Finance. Paper presented at the IIUM International Conference on Islamic Banking and Finance: 'Research and Development: The Bridge between Ideals and Realities'.

[9] Elasrag, Hussein, Global Financial Crisis and Islamic Finance (April 17, 2010).

[10] Farooq, Mohammad Omar, Qard Hasan, Wadiah/Amanah and Bank Deposits: Applications and Misapplications of Some Concepts in Islamic Banking (November 19, 2010). Arab Law Quarterly, Vol. 25, No. 2. Available at SSRN: http://ssrn.com/abstract $=1418202$.

[11] Hanif, Muhammad, Differences and Similarities in I slamic and Conventional Banking (November 19, 2010). International Journal of Business and Social Sciences, Vol. 2, No. 2.

[12] http://aibim.com/content/view/148/77/1/0/

[13] Ibn Arfa (1984) Mukhtesan of Sidi Khalil, as cited in Abdur Rahman I., Doi, Shariah: The Islamic Law, A.S.

[14] Kamali, M. H. (1998). Al-Maqasid al-Shari'ah: The Objectives of Islamic Law. The Muslim Lawyer, 3(1), 1-7. Ibn Ashur, M. A.-T. (2006) Treatise on Maqasid al-Shari'ah (M. E.-T. El-Mesawi, Trans.) Washington: The International Institute of Islamic Thought.

[15] Mirza Vejzagic \& Edib Smolo. Maqasid Al-Shari'ah In Is lamic: An Overview at http://www.academia.edu/1146010/Maqasid_AlShariah_in_Islamic_Finance_An_Overview.

[16] Michael A. Santoro. Rutgers Business School in New Jersey at http://sciencecareers.sciencemag.org/career magazine/previous issues/a rticles/2009_05_22/caredit.a0900066 
[17] Ruzian Markom; Noor Inayah Yaakub.Litigation as dispute resolution mechanism in Islamic finance: Malaysian experience.European Journal of Law and Economics. 2012:1-20.2):417-422.

[18] Wan Kamal Mujani; Ezad Azraai Jamsari; Noor Inayah Ya'akub; Hamzaini Abdul Hamid; Wan Mohtar W an Yusoff; Nur Riza Mohd. Suradi; Zinatul Ashiqin Zain ol; Wan Mohd Hirwani Wan Hussain; Mohamad Abdul Hamid; Adlin Masood; et al..Meaning of leadership according to Is lam. Advances in $\mathrm{Na}$ tural and Applied Sciences. 2012;6(8):1394-1398.

[19] Wan Mohd Hirwani Wan Hussain; Mohd Nizam Abdul Rahman; Zinatul Ashiqin Zainol; Wan Kamal Mujani; Noor Inayah Yaakub. Commercialisation of university research into enginee ring education. Social Sciences. 2011;6(6):502-506.

[20] Wan Kamal Mujani; Hirwani Wan Hus sain; Noor Inayah Yaakub; Rusnadewi Abdul Rashid. Constructions of failure ad delay under
Islamic estate management. International Bus iness Management. 2011;5(6 A):326-330.

[21] Wan Kamal Mujani; Wan Mohd Hirwani Wan Hussain; Noor Inayah Yaakub; Rusnadewi Abdul Ra shid. The Concept of law of gift inter vivos under Islamic law and the contracts act, 1950. International Business Management. 2011;5(6 A):319-325.

[22] Nurdeng Deuraseh; Noor Inayah Yakub.The development of human embryo in the Quran, surah al- mu'minun (23): 12-14. European Journal of Scientific Research. 2010;48(1):155-159.

[23] Wan Kamal Mujani; Noor Inay ah Ya'akub; Wan Mohd Hirwani Wan Hussain; Zinatul Ashiqin Zain ol; Allawati Kasri.Current Islamic theological discourse on middle class.Advances in Natural and Applied Sciences. 2012;6(6):973-979. 